Jurnal Kesehatan Perintis (Perintis's Health Journal) 7 (1) 2020: 41-50

Contents list available at JKP website

Jurnal Kesehatan Perintis (Perintis's Health Journal)

Journal homepage: https://jurnal.stikesperintis.ac.id/index.php/JKP

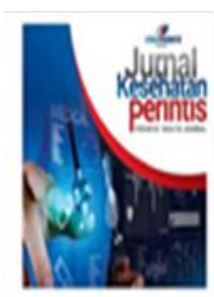

\title{
Aktivitas Triterpenoid Kulit Batang Waru Jawa (Hibiscus tiliaceus L.) Terhadap Bakteri Escherichia coli
}

\author{
Lisa Savitri ${ }^{\star 1}$, Kharisul Ihsan ${ }^{2}$ \\ ${ }^{1}$ Universitas Kadiri, Jawa Timur, Indonesia \\ ${ }^{2}$ Universitas Brawijaya, Jawa Timur, Indonesia
}

Article Information :

Submission:Nov 4, 2019; Revised:Jun 30, 2020; Accepted:Jun 30,2020; Available online: Jul 12, 2020

*Corresponding author : lisasavitri@unik-kediri.ac.id

\begin{abstract}
ABSTRAK
Penyakit infeksi merupakan salah satu masalah kesehatan yang serius, khususnya di negara berkembang. Adanya resistensi antimikroba menyebabkan bahaya penyakit infeksi semakin parah, sehingga menjadi perhatian terbesar bagi kesehatan manusia. World Health Organization (WHO) memperkirakan bahwa pada tahun 2050, septikemia yang disebabkan oleh bakteri resisten antimikroba dapat mengakibatkan 10 juta kematian selama satu tahun. Tujuan penelitian ini adalah untuk melakukan isolasi senyawa triterpenoid yang terkandung dalam tanaman waru jawa (Hibiscus tiliaceus L.) serta melakukan identifikasi terhadap senyawa triterpenoid, dan melakukan pengujian aktivitas antibakteri Escherichia coli. Isolasi triterpenoid dari tanaman waru jawa diawali dengan maserasi menggunakan $\mathrm{n}$-heksana, identifikasi triterpenoid, dan melakukan pengujian untuk aktivitas antibakteri. Hasil penelitian menunjukkan maserasi 3,2 kg serbuk kering kulit batang waru jawa menghasilkan ekstrak kental n-heksana sebesar 13,06 g. Hasil uji fitokimia menggunakan pereaksi Liebermann-Burchard menunjukkan ekstrak kental n-heksana positif mengandung triterpenoid. Pemisahan ekstrak kental n-heksana dengan kromatografi kolom menghasilkan isolat positif mengandung triterpenoid sebanyak 6 fraksi. Hasil identifikasi menggunakan spektrofotometer UV-Vis menunjukkan adanya serapan maksimum untuk fraksi 1, 2, dan 3 pada panjang gelombang 216,50 nm, $217 \mathrm{~nm}$, dan 228,50 nm. Berdasarkan spektrogram FT-IR menunjukkan adanya gugus $\mathrm{C}-\mathrm{C}, \mathrm{C}=\mathrm{O},-\mathrm{C}-\mathrm{H},-\mathrm{CH}_{3},-\mathrm{CH}_{2}$, dan $\mathrm{C}-\mathrm{O}$. Hasil aktivitas antibakteri dengan metode disc diffusion dan pengenceran dalam tabung menunjukkan bahwa fraksi 1, 3, 5, dan crude n-heksana mampu menghambat pertumbuhan bakteri Eschericia coli. MIC terhadap $E$. coli fraksi 1 sebesar $0,2 \mathrm{mg} / \mathrm{mL}$.
\end{abstract}

Kata kunci : triterpenoid, kulit batang waru jawa, resistensi bakteri, antibiotik, Escherichia coli.

\section{ABSTRACT}

Infectious disease is a serious health problem, especially in developing countries. The existence of antimicrobial resistance causes the danger of infectious diseases getting worse, so it is the biggest concern for human health. The World Health Organization (WHO) estimates that by 2050, septicemia caused by antimicrobial resistant bacteria can result in 10 million deaths during one year. The purpose of this study was to isolate triterpenoid compounds contained in the javanese waru plant (Hibiscus tiliaceus L.) as well as to identify triterpenoid compounds, and to test the antibacterial activity of Escherichia coli. Isolation of triterpenoids from javanese waru plants begins with maceration using n-hexane, identification of triterpenoids, and testing for antibacterial activity. 
The results showed that maceration of $3.2 \mathrm{~kg}$ of dry powder of javanese waru bark produced a thick extract of $n$-hexane of $13.06 \mathrm{~g}$. Phytochemical test results using Liebermann-Burchard reagents showed a thick $n$-hexane-thick extract containing triterpenoids. Separation of $n$-hexane viscous extract by column chromatography resulted in 6 fractions of positive isolates containing triterpenoids. The identification results using a UV-Vis spectrophotometer showed the presence of maximum absorption for fractions 1, 2, and 3 at wavelengths of $216.50 \mathrm{~nm}, 217 \mathrm{~nm}$ and 228.50 $\mathrm{nm}$. Based on FT-IR spectrogram shows the presence of $\mathrm{C}-\mathrm{C}, \mathrm{C}=\mathrm{O},-\mathrm{C}-\mathrm{H},-\mathrm{CH}_{3},-\mathrm{CH}_{2}$, and $\mathrm{C}-\mathrm{O}$ groups. The results of the antibacterial activity with the disc diffusion and dilution methods in the tubes showed that fractions 1, 3, 5, and crude n-hexane were able to inhibit the growth of Eschericia coli bacteria. MIC against E. coli fraction 1 was $0.2 \mathrm{mg} / \mathrm{mL}$.

Keywords: triterpenoids, javanese waru bark, bacterial resistance, antibiotics, Escherichia coli.

\section{PENDAHULUAN}

Penyakit infeksi adalah penyebab utama kematian di seluruh dunia. Adanya resistensi antimikroba menyebabkan bahaya penyakit infeksi semakin parah, sehingga menjadi perhatian terbesar bagi kesehatan manusia. Meskipun pendekatan baru sedang diselidiki, World Health Organization (WHO) memperkirakan bahwa pada tahun 2050, septikemia yang disebabkan oleh bakteri resisten antimikroba dapat mengakibatkan 10 juta kematian selama satu tahun (Gestal, et al., 2019). Mikroorganisme utama yang terlibat dalam kontaminasi makanan adalah milik Enterobacteriaceae, dengan spesies paling dominan adalah Escherichia coli. Bakteri ini mewakili satu dari yang paling banyak dipelajari dan merupakan salah satu yang paling utama (Stellato, et al., 2016).

Resistensi antimikroba adalah masalah kesehatan masyarakat utama, dan saat ini, beberapa infeksi bakteri membutuhkan waktu pemulihan yang lama dan mengakibatkan kenaikan dosis yang terus-menerus. Oleh karena itu diperlukan antibiotik baru, dan strategi baru sangat dibutuhkan untuk melawan penyakit menular (Torres-Sangiao, et al., 2016). Penelitian Sharaha, et al. (2019) telah memfokuskan pada diagnosis yang akurat dan dini untuk memerangi infeksi yang lebih baik, sementara beberapa pekerjaan juga telah dilakukan untuk mengidentifikasi mekanisme resistensi pada bakteri, mikobakteri, virus, dan parasit dengan lebih baik. Konsensus adalah untuk fokus pada deteksi dini mikroba, serta kemungkinan mekanisme resistensi, untuk memberikan pengobatan antimikroba yang diperlukan dan menghindari peningkatan lebih lanjut pada resistensi antimikroba (Windels, et al., 2019; Wang dan Ruan, 2017; Sharma, et al., 2017)
Menurut WHO penggunaan obat tradioinal telah lama digunakan di dunia, sekitar $65 \%$ dari penduduk negara maju dan $80 \%$ dari penduduk negara berkembang telah menggunakan obat herbal. Obat herbal merupakan bahan baku sediaan yang berasal dari tumbuhan yang memiliki efek terapi atau efek lain yang bermanfaat bagi kesehatan manusia, sediaan obat herbal diproduksi melalui proses ekstraksi, faksinasi atau proses biologi berisi eksipien atau bahan inert sebagai bahan inert sebagai bahan aktif. Faktor pendorong terjadinya peningkatan penggunaan obat herbal yaitu: meningkatnya harapan hidup pada saat prevalensi penyakit kronik meningkat, adanya kegagalan penggunaan obat modern untuk penyakit degeneratif dan kanker, serta semakin meluasnya akses informasi obat herbal di seluruh dunia (Sihombing dan Octora, 2019). Salah satu tanaman berkhasiat obat adalah tanaman waru jawa (Hibiscus tilaceus L.) yang tumbuh subur di hutan tropis Indonesia, salah satu sebarannya melimpah di Pulau Jawa.

Hibiscus tiliaceus $\mathrm{L}$. adalah tanaman yang mengandung banyak unsur kimia di dalamnya, yang dibutuhkan manusia untuk mengobati banyak penyakit (Samsudin, et al., 2019). Ekstrak $H$. tiliaceus dilaporkan memiliki berbagai kegiatan farmakologis yang menarik seperti sebagai antioksidan, antiinflamasi, anthelmintik dan aktivitas antimikroba (Tambe dan Bhambar, 2014; Ramproshad, et al. 2012; Borhade, et al. 2012). Daun waru dapat digunakan untuk mengobati Tuberkulosis paruparu, batuk, sesak napas, radang amandel (tonsillitis), demam, disentri pada anak, muntah darah, radang usus, bisul, abses, dan rambut rontok (Indah dan Darwati, 2013).

Penelitian yang dilakukan oleh Vijay dan Rajendra (2014) mengungkapkan bahwa studi fitokimia $H$. tiliaceus dengan hasil positif dari 
karbohidrat, protein, steroid, alkaloid, saponin, tanin, glikosida, dan asam amino dari bagian kayu dan daun. Laporan lain dari penelitian Shamsuddin (2013) menggunakan daun $H$. tiliaceus dengan pengujian udang air asin sebagai panduan menyebabkan isolasi dari lima senyawa: $\beta$-amyrin, lupeol, asam $p$ metoksisinamat, gossypol dan asam vanili. Daun waru diduga dapat memiliki aktivitas sebagai antikanker karena secara kemotaksonomi senyawa turunan dapat terdistribusi ke seluruh bagian tumbuhan. Hasil uji toksisitas ekstrak etanol daun waru menghasilkan nilai $\mathrm{LC}_{50}$ 79,43 ppm.

Kandungan yang terdapat dalam tanaman ini dapat untuk menghindari efek samping obat menjadi resisten. Tanaman spesies Hibiscus memiliki senyawa metabolit sekunder yang secara tidak langsung tumbuh normal, berkembang, dan memiliki peranan penting dalam pertahanan tanaman. Senyawa organik tersebut alkaloid, glikosida, terpenoid, fenol, tannin, flavonoid, dan saponin. Beberapa spesies Hibiscus salah satunya Hibiscus tiliaceus L. memiliki bioaktivitas sebagai antimikroba dan antioksidan (Salem, et al., 2014). Penelitian yang telah dilakukan oleh Wong, et al., 2010 menunjukkan bahwa triterpenoid yang telah berkembang menyatakan kulit batang kayu dari Hibiscus tiliaceus L. mempunyai aktivitas sebagai antibakteri. Ekstrak etanol Hibiscus tiliaceus L. asal Thailand memiliki aktivitas menghambat bakteri gram positif Staphylococcus aureus, bakteri gram negatif Escherichia coli, serta Salmonella paratyphi (Maganha, et al., 2010).

Senyawa yang menghambat aktivitas pertumbuhan bakteri salah satunya adalah terpenoid. Senyawa ini dapat diisolasi dari tanaman berfamili Hibiscus. Salah satu turunannya adalah triterpenoid yang menghambat pertumbuhan bakteri (Manzano, et al., 2013). Tanaman berfamili Hibiscus yang senyawa triterpenoidnya belum pernah diteliti salah satunya adalah spesies Hibiscus tiliaceus L., sehingga hal tersebutlah yang membedakan penelitian ini dengan penelitian sebelumnya. Berdasarkan uraian di atas, penelitian ini bertujuan untuk melakukan isolasi senyawa triterpenoid yang terkandung dalam tanaman waru jawa (Hibiscus tiliaceus L.) serta melakukan identifikasi terhadap senyawa triterpenoid, dan melakukan pengujian aktivitas antibakteri Escherichia coli, sehingga diharapkan senyawa triterpenoid dari tanaman waru jawa dapat dijadikan sebagai kandidat obat antibakteri, khususnya Escherichia coli.

\section{METODE PENELITIAN}

Alat yang digunakan pada penelitian ini yaitu seperangkat alat gelas, maserator, rotary evaporator vacum, oven, inkubator, spektrofotometer UV-Vis Shimadzu dan FT-IR. Bahan yang digunakan antara lain metanol, etanol, etil asetat, n-heksana, kit reagen uji metabolit sekunder asam sulfat pekat, etil asetat, sodium hidroksida, silika gel 60, asam asetat anhidrid, plat KLT, kertas saring, pipa kapiler, $\mathrm{BaCl}_{2} .2 \mathrm{H}_{2} \mathrm{O}$, nutrient agar (NA), bakteri E.coli. Sampel waru jawa diperoleh dari Kota Lamongan yang diidentifikasi taksonominya di Laboratorium Taksonomi Tanaman, Jurusan Biologi, Universitas Brawijaya.

Tahapan Penelitian (1)Persiapan Kulit Batang Waru Jawa : Sampel kulit batang waru jawa (Hibiscus tilliaceus L.) dikumpulkan dari Kota Lamongan, dibersihkan, dipotong kecilkecil 3-5 cm, dikeringkan, serta digiling menjadi serbuk. Sebanyak $\pm 9 \mathrm{~kg}$ sampel siap digunakan. (2) Pengujian Fitokimia Kulit Batang Waru Jawa: Serbuk kulit batang waru jawa sebanyak 30 gram dimasukkan dalam maserator. Kemudian diekstrak dengan 250 $\mathrm{mL}$ pelarut air, metanol, etil asetat, dan $\mathrm{n}$ heksana, kemudian dianalisis keberadaan metabolit sekunder. (3) Ekstraksi Senyawa Triterpenoid : Sebanyak $400 \mathrm{~g}$ sampel serbuk Hibiscus tilliaceus L. direndam dengan $\mathrm{n}$ heksana, didiamkan 7 hari, kemudian disaring. Larutan sampel dipekatkan dengan rotary evaporator vacum diperoleh ekstrak murni. Selanjutnya ekstrak dituangkan dalam wadah steril dan disimpan pada temperatur $4-7^{\circ} \mathrm{C}$. (4) Pemisahan Senyawa Triterpenoid : Ekstrak positif triterpenoid dianalisis KLT dengan fase gerak n-heksana:etil asetat (10:0); (9:1); (8:2); (7:3); (6:4); (5:5) dan fase diam plat silika gel 60 GF254, sehingga diperoleh noda-noda isolat yang dapat ditentukan nilai $R f$ dan dilakukan pemisahan kromatografi kolom (silika gel 60, n-heksana:etil asetat (8:2); (5:5); etil asetat; dan etanol. (5) Identifikasi Senyawa Triterpenoid : Hasil kromatografi kolom diuji KLT menggunakan eluen (8:2), yang menghasilkan satu spot noda dikelompokkan menjadi kelompok fraksi dan diuji dengan reagen Liberman-Burchad untuk mengetahui senyawa triterpenoid. Fraksi positif triterpenoid diuji kemurnian KLT. Apabila menghasilkan 
satu noda maka fraksi tersebut diidentifikasi menggunakan spektrofotometer FT-IR dan UV-Vis. (6) Uji Aktivitas Antibakteri

Pembuatan Media Agar dan Suspensi Bakteri Uji : Sebanyak $11 \mathrm{~g}$ nutrient agar (NA) dilarutkan dalam air steril $100 \mathrm{ml}$, dipanaskan hingga larut, ditutup kapas steril. disterilkan dengan autoklaf selama 15 menit. Bakteri ditanam pada media pertumbuhan nutrient agar (NA) miring dan diinkubasi pada suhu $37^{\circ} \mathrm{C}$ selama 24 jam. Bakteri uji disuspensikan dengan menumbuhkan bakteri dalam media cair, kemudian diinkubasi selama 24 jam pada suhu $37^{\circ} \mathrm{C}$. Syarat jumlah bakteri uji sensitivitas yaitu $10^{5}-10^{8} \mathrm{CFU} / \mathrm{mL}$.

Pengujian Aktivitas Antibakteri Sebanyak $200 \mu \mathrm{L}$ suspensi bakteri ditambahkan dalam $20 \mathrm{~mL}$ media NA untuk bakteri. Campuran diputar hingga homogen, didinginkan menjadi padat dalam cawan petri steril. Dibuat cakram berdiameter $\pm 4,79 \mathrm{~mm}$ dimasukkan $50 \mu \mathrm{L}$ masing-masing sampel ke dalam cakram dan dimasukkan dalam cawan petri yang telah ada bakteri. Inkubasi dilakukan pada $30^{\circ} \mathrm{C}$ selama 16 jam. Diameter hambat diamati setelah periode inkubasi.

Metode dillution yaitu fraksi uji $(0,1 ; 0,2$; 0,$4 ; 0,8 \mathrm{mg} / \mathrm{mL}$ ) dilarutkan dengan tween 20 dalam tabung steril medium cair nutrient broth masing-masing $1 \mathrm{~mL}$. Disiapkan suspensi bakteri stok konsentrasi 0,5 McFarland dan suspensi bakteri uji, ditambahkan dalam setiap fraksi hingga volume menjadi $2 \mathrm{~mL}$. Diukur Optical Density (OD) sebelum dan sesudah inkubasi.

\section{HASIL DAN PEMBAHASAN}

Tahap pertama adalah proses penyiapan sampel tanaman waru jawa dari Kota Lamongan. Tanaman waru jawa yang digunakan ditunjukkan pada gambar 1 dan sampel kulit batang untuk penelitian pada gambar 2. Di samping itu, spesimen tanaman dilakukan analisis taksonomi untuk memastikan spesies tanaman di Laboratorium Taksonomi Jurusan Biologi FMIPA, Universitas Brawijaya dilakukan oleh Dr. Serafinah Indriyani, M.Si.

Hasil uji fitokimia menunjukkan triterpenoid terekstrak secara optimal dengan pelarut n-heksana. Hal ini dibuktikan pada uji kualitatif ekstrak n-heksana yang diperoleh dari uji alkaloid, flavonoid dan fenolik menunjukkan hasil negatif. Pada uji triterpenoid menunjukkan hasil uji positif yang pekat, mengindikasikan triterpenoid terekstrak dalam jumlah banyak.

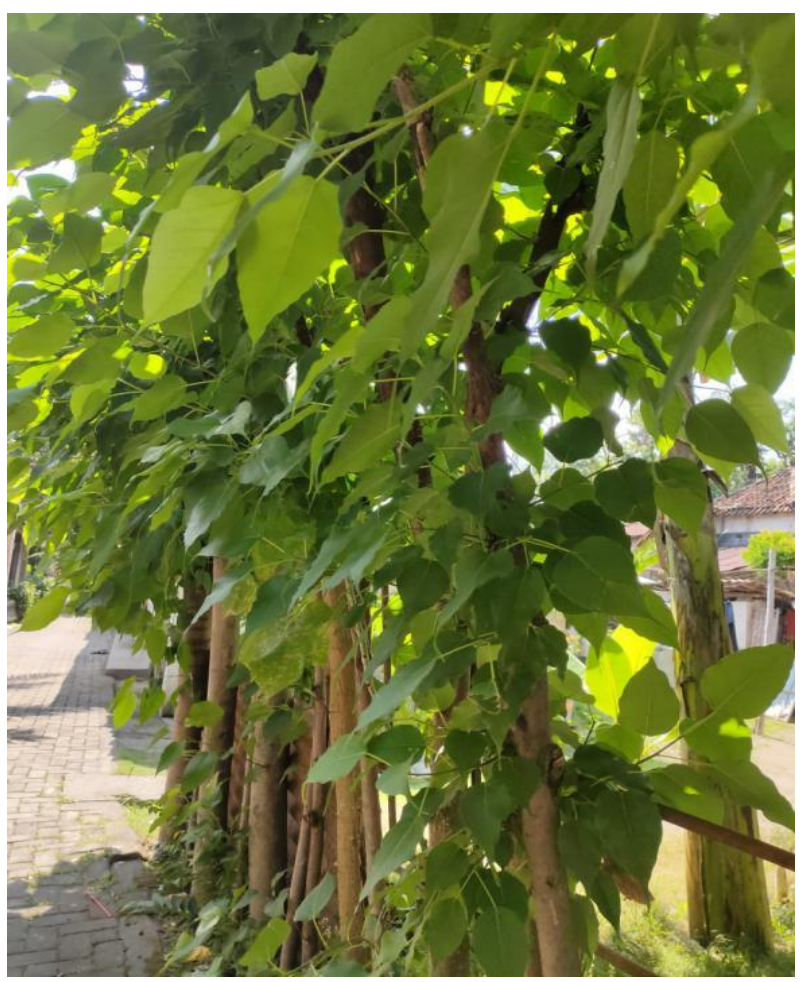

\section{Gambar 1. Foto Tanaman Waru Jawa}

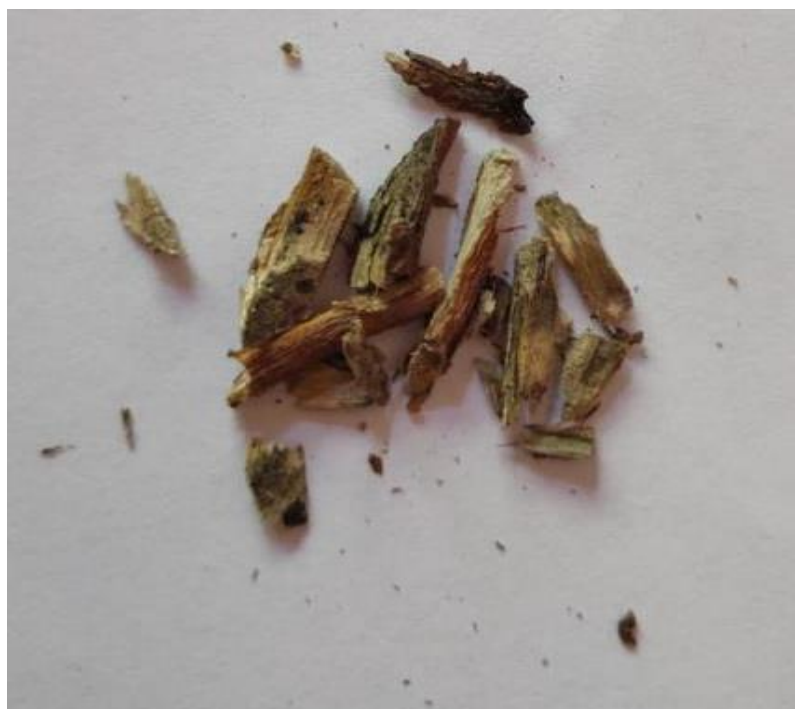

\section{Gambar 2. Sampel Kulit Batang Waru Jawa}

Untuk pelarut selain n-heksana terdapat campuran beberapa senyawa yang terekstrak.

Hasil maserasi menggunakan n-heksana ditunjukkan pada gambar 3. Hasil yang diperoleh dari empat ulangan yaitu rata-rata 3,2 g. Ekstrak dari kulit batang waru jawa sebanyak $9 \mathrm{~kg}$ diperoleh total crude $\mathrm{n}$-heksana 
sebesar 13,06 g dengan warna kuning kecoklatan. Pemisahan triterpenoid diawali menentukan eluen yang tepat menggunakan KLT dan diketahui eluen untuk memisahkan komponen-komponen metabolit sekunder dengan baik adalah $n$-heksana:etil asetat (8:2) disebabkan pemisahan dan memiliki Rf yang bagus sebesar 0,02 pada $\mathrm{Rf}$ terbawah. Pemisahan triterpenoid dengan kromatografi kolom diperoleh 62 botol penampungan \pm 50 $\mathrm{mL}$ warna hijau, kuning pekat, kuning, kuning pucat, dan tidak berwarna.

Hasil KLT dengan nilai Rf spot noda sama dikelompokkan menjadi satu, dan diperoleh sebanyak tujuh fraksi seperti pada tabel 1. Sedangkan untuk uji fitokimia hasil kolom 1, 2, $3,6,8,9,10,17,33,34,36,39,41$, dan 43 positif mengandung triterpenoid.

Hasil kolom 45 dan 54 negatif triterpenoid karena fraksi 45-62 tidak berwarna berupa pelarut etanol. Identifikasi senyawa triterpenoid pada fraksi 1, 2, dan 3, fraksi yang dimaksud seperti pada tabel 1, untuk fraksi 4-6 tidak dilakukan identifikasi FT-IR dan UV-Vis karena

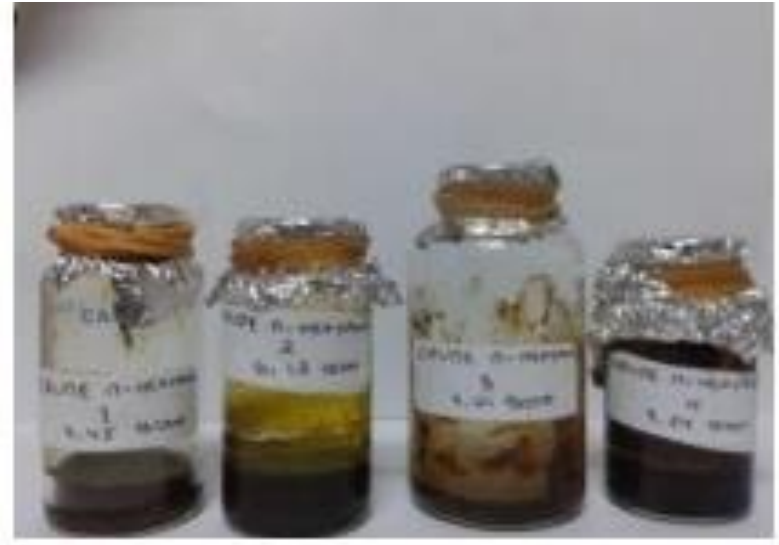

\section{Gambar 3. Foto Hasil Maserasi Menggunakan n-heksana}

hasil spektrum yang tampak tumpang tindih antara campuran triterpenoid yang belum murni dan didukung dengan hasil KLT menunjukkan spot noda lebih dari satu.

Hasil karakterisasi pada isolat relatif murni triterpenoid dengan spektrofotometri UV-Vis menunjukkan $\lambda$ maks fraksi 1 sebesar.

Tabel 1. Fraksi Hasil Kolom

\begin{tabular}{cccc}
\hline Fraksi & $\begin{array}{c}\text { Hasil Kolom } \\
\text { (botol) }\end{array}$ & Keterangan Hasil KLT & $\begin{array}{c}\text { Massa Hasil Evaporasi } \\
\mathbf{( g )}\end{array}$ \\
1 & $2-5$ & Satu spot & 5,07 \\
2 & $17-32$ dan $41-42$ & Satu spot & 3,11 \\
3 & $33-40$ dan $43-44$ & Satu spot & 0,2 \\
4 & 8 & Dua spot & 0,16 \\
5 & $9,10-16$ & Tiga spot & 2,13 \\
6 & $6-7$ & Empat spot & 0,24 \\
7 & $45-62$ & Tidak terdapat spot & - \\
\hline
\end{tabular}

$216,50 \mathrm{~nm}$; fraksi 2 sebesar $217 \mathrm{~nm}$; dan fraksi 3 sebesar 228,50 nm

Berdasarkan karakterisasi UV-Vis dan didukung spektrum IR yang tercantum pada gambar 4, 5 dan 6 dapat diketahui tiga fraksi triterpenoid pada panjang gelombang tersebut diduga adanya transisi elektronik pada $n-\sigma^{*}$ dari kromofor $\mathrm{C}=\mathrm{O}$. Berdasarkan penelitian triterpenoid sebelumnya yang dilakukan oleh Hossain dan Ismail (2013) menunjukkan bahwa isolasi daun kumis kucing (Orthosiphon stamineus) memiliki tujuh triterpenoid, asam ursolat, asam oleanolic, asam betulinic, asam hydroxybetulinic, maslinic acid, a-amyrin dan $\beta$-amyrin. Struktur senyawa ini telah dibentuk oleh spektrofotometri metode scopic. Lebih lanjut penelitian lain yang dilakukan oleh Santoni, et al. (2019) menyatakan bahwa isolasi triterpenoid dari ekstrak n-heksana daun kayu ara (Ficus aurata (Miq.) Miq) dengan spektra UV menunjukkan adanya ikatan rangkap dalam senyawa terisolasi pada 204 nm $\lambda$ max dan IR spektra menunjukkan gugus fungsi $-\mathrm{OH}$ pada $3290 \mathrm{~cm}^{-1},-\mathrm{CH}$ membentang di $2912,90 \mathrm{~cm}^{-1}, C=C$ pada $1676 \mathrm{~cm}^{-1}$, Peregangan C-O pada $1054,93 \mathrm{~cm}^{-}$ 1, dan pada $1374 \mathrm{~cm}^{-1}$ adalah spektrum senyawa geminal dimethyl yang merupakan karakteristik triterpenoid yang mendukung data spektroskopi ultraviolet.

Hasil analisis FT-IR terhadap fraksi 1(gambar 4), 2 (gambar 5), dan 3 (gambar 6) 
memberi indikasi keberadaan gugus fungsi dengan serapan rentangan $\mathrm{C}-\mathrm{H}$ alifatik ditunjukkan adanya pita serapan tajam dengan intensitas kuat pada zona 2 daerah bilangan gelombang $3000 \mathrm{~cm}^{-1}-2800 \mathrm{~cm}^{-1}$. Indikasi tersebut menunjukkan adanya gugus metil $\left(\mathrm{CH}_{3}\right)$ dan metilena $\left(\mathrm{CH}_{2}\right)$ yang diperkuat dengan vibrasi tekuk -C-H pada zona 4

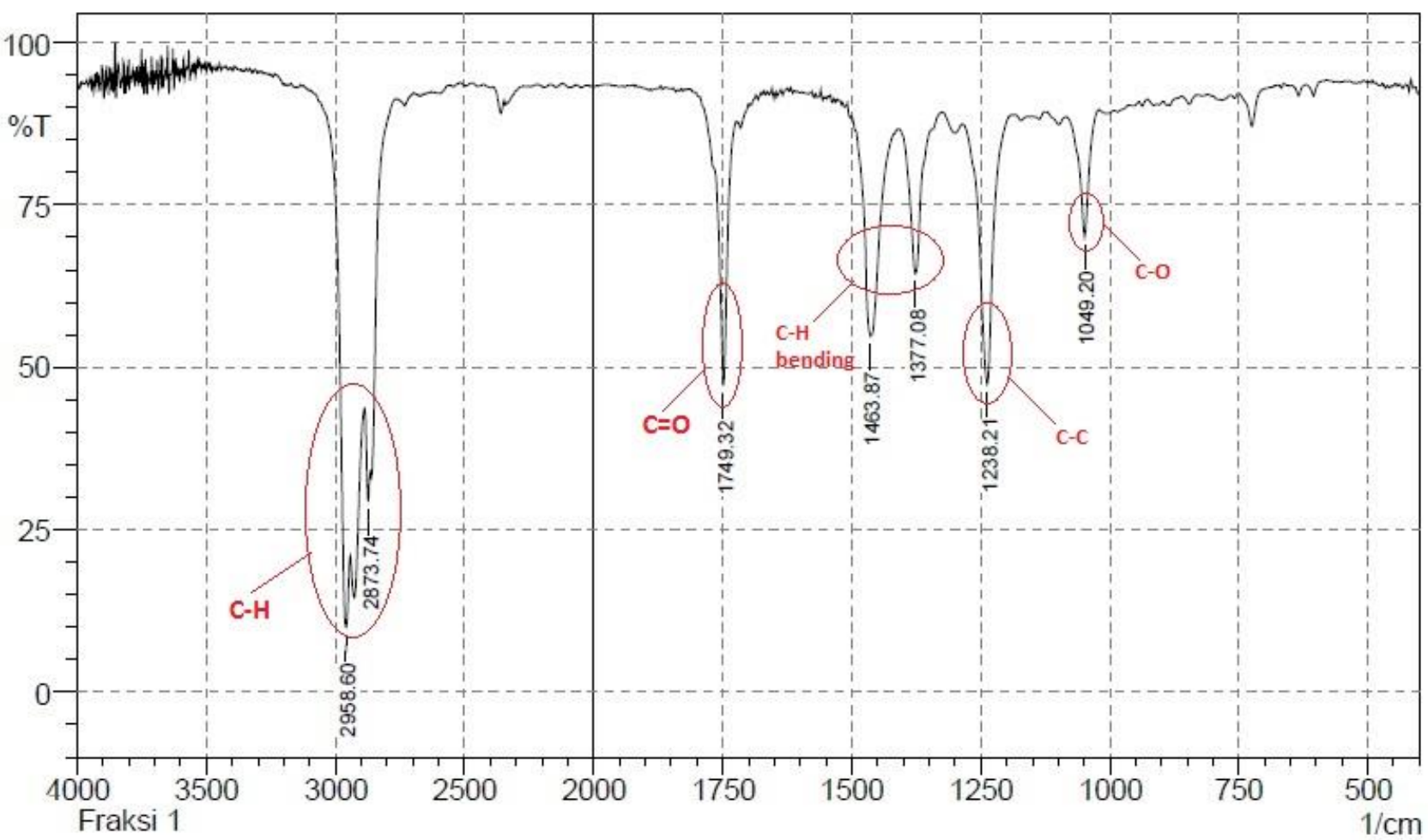

Gambar 4. Profil Spektrum IR Fraksi 1

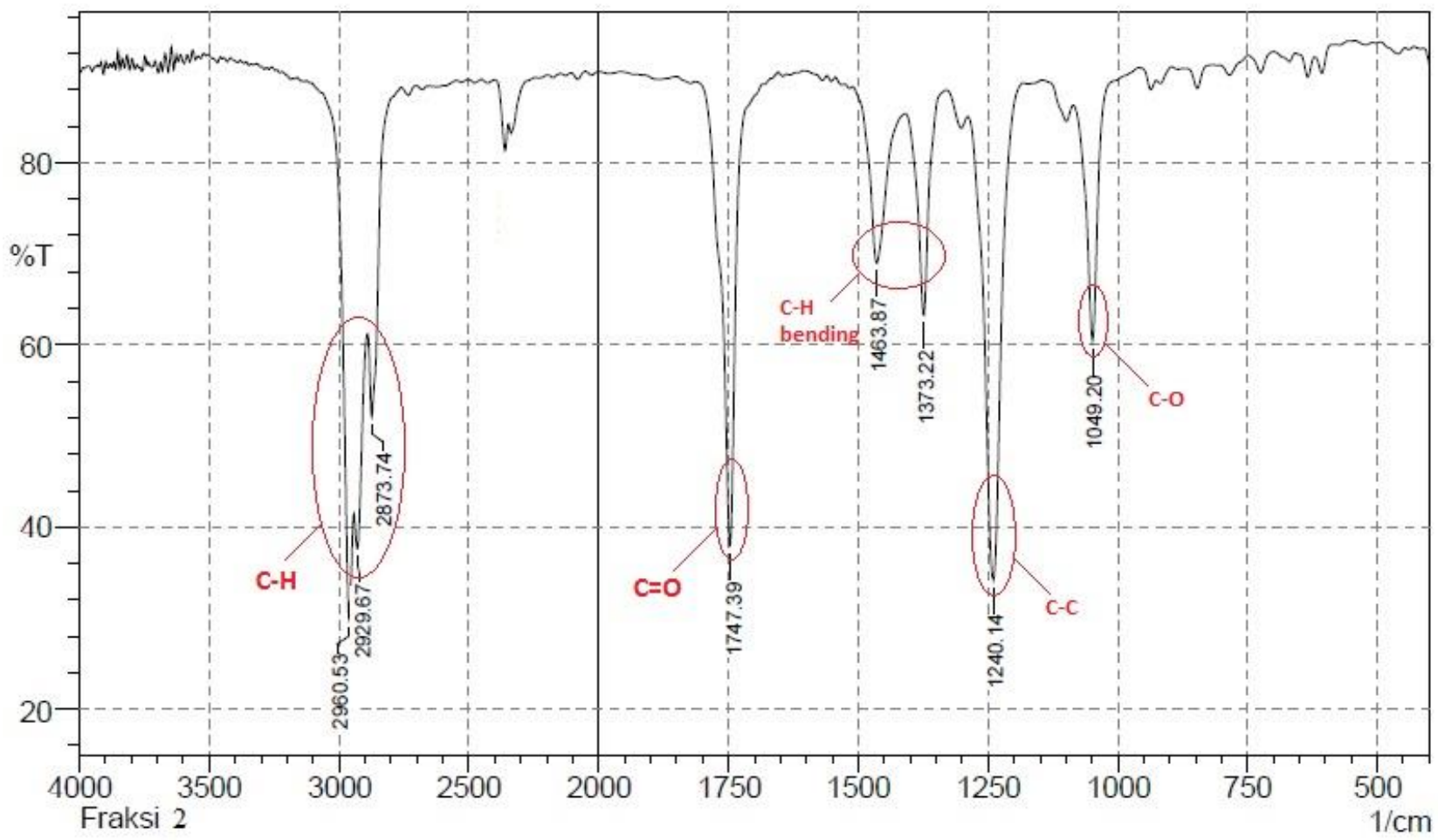

Gambar 5. Profil Spektrum IR Fraksi 2 


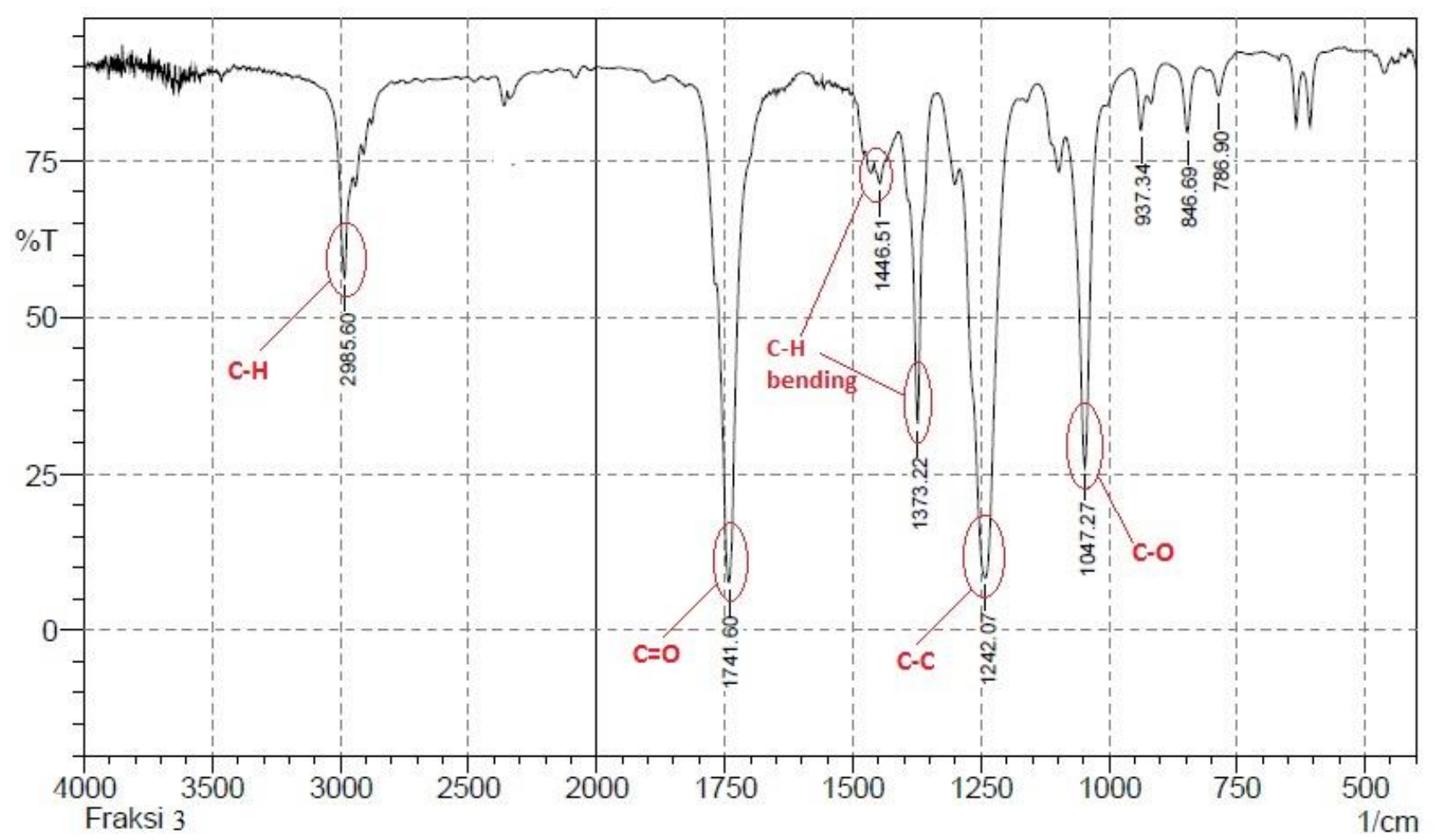

Gambar 6. Profil Spektrum IR Fraksi 3

daerah bilangan gelombang 1463,87 cm-1 dan $1377,08 \mathrm{~cm}-1$ yang merupakan serapan dari bengkokan $-\mathrm{CH}_{2}$ dan $-\mathrm{CH}_{3}$ mengindikasikan adanya senyawa triterpenoid [20]. Serapan kuat pada daerah bilangan gelombang $1749,32 \mathrm{~cm}^{-1}$ indikasi adanya gugus fungsi $\mathrm{C}=\mathrm{O}$ dari ester diperkuat pada bilangan gelombang $1049,20 \mathrm{~cm}^{-1}$ yang merupakan vibrasi ulur C-O. Adanya serapan pada $1242,07 \mathrm{~cm}^{-1}$ mengindikasikan adanya vibrasi ulur C-C. Ketiga fraksi hasil pemisahan menunjukkan spektrum IR pada daerah bilangan gelombang yang sama. Hal ini mengindikasi bahwa tiga fraksi tersebut merupakan satu golangan senyawa triterpenoid.

Pada tabel 2 menunjukkan bahwa konsentrasi hasil isolat triterpenoid dari kulit batang waru jawa (Hibiscus tiliaceus L.) berpengaruh terhadap diameter zona hambat pada bakteri $E$. coli. Hasil penelitian fraksi 1-6 dan crude n-heksana pada tabel 2 disesuaikan dengan tabel 3 menunjukkan bahwa fraksi triterpenoid hasil isolasi memiliki daya hambat sedang. Pada beberapa penelitian melaporan bahwa berdasarkan penelitian in vitro yang pernah dilakukan pada proses ekstraksi bawang putih yang digunakan sebagai antibakteria pada bakteri Escherichia coli dan Salmonella typhi didapatkan hasil bahwa ekstrak etanol memiliki efek penghambatan lebih tinggi dibandingkan ekstrak yang menggunakan pelarut air yang menunjukkan sedikit atau tidak ada efek penghambatan (Mikaili, et al., 2013). Namun hasil penelitian tidak menunjukkan adanya pengaruh fraksi terhadap zona hambat bakteri gram negatif $E$. coli seperti ditunjukkan pada tabel 2. Hal ini disebakan pada pengujian aktivitas antibakteri menggunakan metode cakram pelarutan fraksi menggunakan n-heksana yang sulit untuk bercampur dengan suspensi bakteri menggunakan pelarut air. Karena adanya perbedaan polaritas yang tinggi sehingga menyebabkan aktivitas golongan triterpenoid hasil isolasi tidak bekerja optimal.

Pengujian aktivitas antibakteri menggunakan metode dillution untuk mengetahui konsentrasi terkecil dari fraksi yang dapat menghambat atau MIC yang dapat dilihat pada tabel 2. Hasil penelitian menunjukkan aktivitas antibakteri paling baik dalam menghambat bakteri gram negatif yaitu pada fraksi 1 konsentrasi sebesar $0,2 \mathrm{mg} / \mathrm{mL}$ sudah dapat menghambat aktivitas bakteri $E$. coli. Pada crude n-heksana sebelum dilakukan 


\section{Konsentrasi Uji Bakteri E. coli $(\mathrm{mg} / \mathrm{mL})$}

\begin{tabular}{|c|c|c|}
\hline \multirow[t]{2}{*}{ Fraksi Uji } & 0,1 & 0,2 \\
\hline & \multicolumn{2}{|c|}{ Zona diame } \\
\hline Fraksi 1 & - & - \\
\hline Fraksi 2 & - & - \\
\hline Fraksi 3 & - & 5,31 \\
\hline Fraksi 4 & - & - \\
\hline Fraksi 5 & 6,86 & - \\
\hline Fraksi 6 & - & - \\
\hline Crude n-heksana & 6,92 & - \\
\hline \multicolumn{3}{|l|}{$\begin{array}{l}\text { Kontrol positif } \\
\text { (tetracyclin) }\end{array}$} \\
\hline \multicolumn{3}{|l|}{$\begin{array}{l}\text { Kontrol negatif ( } \mathrm{n}- \\
\text { heksana) }\end{array}$} \\
\hline \multicolumn{3}{|c|}{ el 3. Kategori Daya Hambat Bakteri } \\
\hline $\begin{array}{c}\text { Daya hambat } \\
\text { bakteri } \\
\geq 20 \mathrm{~mm} \\
10-20 \mathrm{~mm} \\
5-10 \mathrm{~mm} \\
\leq 5 \mathrm{~mm}\end{array}$ & $\begin{array}{r}\text { Sanga } \\
\text { Ku } \\
\text { Sed } \\
\text { Len }\end{array}$ & \\
\hline
\end{tabular}

pemisahan tidak memiliki MIC (konsentrasi hambat terkecil). Hal ini disebabkan dalam crude n-heksana terdapat banyak campuran fraksi golongan triterpenoid yang belum dipisahkan dan tidak memiliki aktivitas sebagai antibakteri, sehingga memberikan dampak melemahnya aktivitas antibakteri golongan triterpenoid pada fraksi 1, 3, dan 6 .

\section{KESIMPULAN}

Senyawa golongan triterpenoid berhasil diisolasi dari kulit batang tanaman waru jawa (Hibiscus tiliaceus L.) berasal dari Kota Lamongan yang diperoleh enam fraksi golongan triterpenoid yang ditunjukkan berdasarkan uji fitokimia, UV-Vis, FT-IR, dan kromtografi lapis tipis. Berdasarkan uji aktivitas antibakteri, enam fraksi triterpenoid hasil isolasi memiliki aktivitas menghambat bakteri Escherichia coli yang ditunjukkan dengan zona diameter hambat dan MIC pada fraksi 1, 3, dan 5 sebesar 0,2 ; 0,8; dan $0,4 \mathrm{mg} / \mathrm{mL}$, sedangkan kontrol positifnya (tetracyclyn) menunjukkan diameter zona hambat 25,56 $\mathrm{mm}$.

\section{UCAPAN TERIMA KASIH}

Ucapan terimakasih disampaikan kepada Laboratorium Kimia dan Laboratorium Taksonomi Jurusan Biologi FMIPA Univeritas Brawijaya yang telah menyediakan tempat untuk penelitian dan pengambilan data.

\section{REFERENSI}

Borhade PS, Dalal PS, Pachauri AD, Lone KD, Chaudhari NA, Rangari PK (2012) Evaluation of anti-inflammatory activity of Hibiscus tiliaceus Linn wood extract. Int Journal Res Pharm Biomed Sci 3(3):1246-1250.

Gestal, M.C., Dedloff, M.R., and Sangiao, E.T. 2019. Review Computational Health Engineering Applied to Model Infectious Diseases and Antimicrobial Resistance 
Spread. Appl. Sci. Journal (9) doi:10.3390/app912248

Hossain, M.A., Ismail, Z. Isolation and characterization of triterpenes from the leaves of Orthosiphon stamineus. Arabian Journal of Chemistry (2013) 6, 295-298.

Indah S.Y. dan Darwati, 2013, Keajaiban Daun Tumpas Tuntas Penyakit Kanker, Diabetes, Ginjal, Hepatitis, Kolesterol, Jantung, Graha Pustaka, Jakarta, h. 60.

Maganha, E. G., Halmenschlager, R. D. C., Rosa, R. M., Henriquest, J. A. P., Ramos, A. L. L. D. P., dan Saffi, J. 2010. Pharmacological Evidences for the Extracts and Secondary Metabolites from Plants of the Genus Hibiscus. Food Chemistry Journal, 118(1), 1-10.

Manzano, Patricia I., Migdalia Miranda, Juan Abreu Payrol, Mario Silva, Olov Sterner, and Esther L. Peralta. 2013, Pentacyclic triterpenoids with antimicrobial activity from the leaves of Vernonanthura patens (Asteraceae). Emirates Journal of Food and Agriculture 25, 7, 1-10.

Mikaili, P., Maadirad, S., Moloudizargari, M., Aghajanshakeri, S., Sarahrodi, S. 2013. Therapeutic Uses and Pharmacological Properties of Garlic, Shallot, and Their Biologically Active Compounds. Iranian Journal of Basic Medical Sciences Vol. 16 (10). Pp. 1031-48.

Ramproshad S, Afroz T, Mondal B, Haque A, Ara S, Khan R, Ahmed S (2012) Antioxidant and antimicrobial activities of leaves of medicinal plants Hibiscus tiliaceus L. Pharmacol Online Journal, 3:82-87.

Rita, W. S., 2010, Isolasi, Identifikasi, dan Uji Aktivitas Antibakteri Senyawa Golongan Triterpenoid pada Rimpang Temu Putih (Curcuma zedoaria (Berg.) Roscoe), Jurnal Kimia, 4(1), 20-26.

Salem, M. Z. M., O-Perez, A. Z. M. Salem, 2014, Studies on Bioloical Activities and Phytochemicals Composition of Hibiscus Species-A Review, Life Science Journal, 11(5), 1-8.

Samsudin, Andriani, Sarjono, Syamsumir. 2019. Study on Hibiscus tiliaceus Leaves as Antibacterial an Antioxidant Agents. Alotrop, Jurnal Pendidikan dan IImu Kimia, 2019: 3 (2):123-131.

Santoni, A., Efdi, M., Bumali, R. Isolasi Senyawa Triterpenoid dan Uji Antibakteri Ekstrak n-Heksan Daun Kayu Ara (Ficus aurata (MIQ.) MIQ). Jurnal Riset Kimia: 2019, 10 (1).

Savitri, N.H., Indiastuti, D.N., Wahyunitasari, M.R. Inhibitory Activity of Allium sativum L. Extract Againts Streptococcus pyogenes and Pseudomonas aeruginosa. Journal of Vocational Health Studies 03 (2019): 7277.

Shamsuddin, A.A., M. Najiah, A., Suvik, M.N., Azariyah, B.Y., Kamaruzzaman, A.W., Effendy, et al. Antibacterial Properties of Selected Mangrove Plants Againts Vibrio Species and Its Cytottoxicity Againts Artemiasalina, World Applied Sciences Journal, 2013: 25 (2), 333-340.

Sharaha, U.; Rodriguez-Diaz, E.; Sagi, O.; Riesenberg, K.; Lapidot, I.; Segal, Y.; Bigio, I.J.; Huleihel, M.; Salman, A. 2019. Detection of extended-spectrum betalactamase-producing escherichia coli using infrared microscopy and machinelearning algorithms. Anal. Chem. Journal.

Sharma, A.; Hill, A.; Kurbatova, E.; van der Walt, M.; Kvasnovsky, C.; Tupasi, T.E.; Caoili, J.C.; Gler, M.T.; Volchenkov, G.V.; Kazennyy, B.Y.; et al. 2017. Estimating the future burden of multidrug-resistant and extensively drug-resistant tuberculosis in india, the philippines, russia, and south africa: A mathematical modelling study. Lancet Infect. Dis. Journal, 17, 707-715

Sihombing, Y.R. dan Octora, D.D. Uji Imunomodulator dari Ekstrak Etanol Daun Waru (Hibiscus tilaceus) dengan Metode Hipersensitivitas Tipe Lambat. 2019. Jurnal Penelitian Farmasi Herbal, 1 (2)

Stellato, G.; Storia, A.L.; Filippis, F.D.; Borriello, G.; Villani, F.; Ercolini, D. 2016. Overlap of spoilage-associated microbiota between meat and the meat processing environment in small-scale and largescale retail distributions. Appl. Environ. Microb. Journal, 82, 4045-4054

Tambe V, Bhambar R (2014) Phytochemical screening and anthelmintic activity of wood and leaves of Hibiscus tiliaceus Linn. World Journal Pharm, Pharm Sci 3(10):880-889

Torres-Sangiao, E.; Holban, A.M.; Gestal, M.C. 2016. Advanced nanobiomaterials: Vaccines, diagnosis and treatment of infectious diseases. Molecules Journal, 21

Vijay, T., Rajendra, B. Phytochemical Screening and Anthelmintic Activity of 
Wood and Leaves of Hibiscus tiliaceus Linn. World Journal of Pharmacy and Pharmaceutical Science, 2014: 3 (10): 880-889.

Wang, L.; Ruan, S. 2017. Modeling nosocomial infections of methicillinresistant staphylococcus aureus with environment contamination. Sci. Rep. Journal, 7, 580 .

Windels, E.M.; Michiels, J.E.; Fauvart, M.;
Wenseleers, T.; Van den Bergh, B.; Michiels, J. 2019. Bacterial persistence promotes the evolution of antibiotic resistance by increasing survival and mutation rates. ISME Journal.

Wong, S. K., Lim, Y. Y., \& Chan, E. W. C., 2010. Evaluation of antioxidant, antityrosinase and antibacterial activities of selected Hibiscus species. Ethnobotanical Leaflets, 7, 9. 